$\begin{array}{llll}\text { Submitted } & : 21.09 .2020 \\ \text { Accepted } & : 15.11 .2020 & \\ \text { Year } & : \text { December 2020 Volume: } 1 \quad \text { Issue: } 2 \\ \text { DOI } & : 10.47333 / \text { modernizm.2020265879 }\end{array}$

\title{
IMMANUEL KANT'TAN MICHEL FOUCAULT'YA AYDINLANMA SORUNSALI VE MODERNLIK
}

\author{
Himmet Hülür ${ }^{1}$ \\ Ufuk Bircan ${ }^{2}$
}

\begin{abstract}
$\ddot{O} \mathbf{z}$
Immanuel Kant, "Aydınlanma nedir? Sorusuna Yanıt" başlıklı yazısında aydınlanmanın kişisel bir çaba ve atılımla gerçekleşebileceğini savunmuştur. Bu bakımdan aydınlanma öncelikle kişisel düzeyde ele alınmaktadır. Aydınlanma bir kimsenin kendi aklını başkalarının yönlendirmesi olmadan kullanmaya cesaret etmesiyle meydana gelir. Bir kimsenin ergen olmayıştan çıkması ve aydınlanması sadece kendi doğasında bulunan aklı kullanmasını gerektirir. Bu da kişinin kendi iradesiyle kendisini yönlendirecek tek otorite olduğunu, özerk bir varlık olduğunu fark etmesiyle mümkündür. Orta Çağda dogmaların belirlediği akıl bundan böyle kendi kendisine yeterli hale gelmektedir. Böylece insan tarihte ilk defa kendi kendine yeten bir özne olarak ortaya çıkmaktadır. Bu tür bir özne kavrayışı modern düşüncenin temelinde bulunur. Ancak buradaki temel sorunlardan biri, kişinin aklını kullanma cesaretini gösterebileceği koşulun nasıl bulunacağıyla ilgilidir. $\mathrm{Bu}$ anlamda aydınlanmanın bireyin ergin olmayıştan çıkmasıyla sınırlandırılamayacağı, bireyleri aşan bir koşula ihtiyaç duyduğu söylenebilir. Zaman ve mekandaki, Doğu ve Batı, geçmiş ve bugün arasındaki farklar aydınlanmanın koşullarını belirler. Bireyler içinde yaşadıkları toplumsal dünyanın ve tarihsel koşulların imkân verdiği ölçüde akıllarını kullanmaya cesaret edebilirler ve özgür bir biçimde düşünebilirler. $\mathrm{Bu}$ değerlendirmelerle birlikte Kant'n aydınlanma nedir sorusuna verdiği cevapta özne ve özgürlüğü vurgulamasıyla modernizmin temel parametrelerinden birini formüle ettiğini görmekteyiz. Özne, aydınlanmanın olduğu gibi modernizmin de temelinde yer alan bir kurucu unsurdur. Özne, bağımsız anlama ve düşünme çabasına girişebilmenin olmazsa olmaz imkanını sağlamaktadır. Öznenin bu şekilde tarihsel imkan bulmasıyla genel olarak felsefi modernizmin özel olarak ise modernist bilim ve estetik değerlendirmelerin önü açılmıştır. Bu makalede Kant'ın kendi metinlerinden hareketle aydınlanma ve modernlik konusundaki görüşleri irdelenmekte, bu görüşlerin günümüzde bulduğu başlıca yankılar üzerinde durulmakta ve bu bağlamda özellikle Michel Foucault'nun değerlendirmeleri dikkate alınmaktadır.
\end{abstract}

Anahtar sözcükler: Immanuel Kant, Aydınlanma, Modernlik, Özne, Özgürlük, Güncellik.

\section{THE PROBLEM OF ENLIGHTENMENT AND MODERNITY FROM IMMANUEL KANT TO MICHEL FOUCAULT}

\begin{abstract}
In his text titled "An Answer to the Question: What is Enlightenment?" Kant defended that enlightenment could be achieved by a personal effort and breakthrough. In this respect enlightenment is primarily taken into consideration at the personal level. Enlightenment starts with the courage to use one's own reason without directions from others. Enlightenment as extricating oneself from minority requires only using reason inherent in humankind. This is possible through realization that she/he is the only authority who should direct himself/herself and that she/he is an autonomous being. The reason which was determined by dogmas in the Middle Ages becomes self-sufficient from now on. In this way human being comes out for the first time in history as a self-sufficient subject. Such a conception of subject is the identifier of modern thought. But the problem here is about how to find the condition where one would freely use his/her reason. In this sense, it can be said that enlightenment cannot be limited with individual's extricating himself/herself from minority, that it needs a condition that transcends individuals. The differences in times and space, between East and West, past and present determines these enlightenment conditions. Individuals can show courage and think freely in the extend that their social world and historical conditions permit them to do so. With these considerations, in Kant's answer to the question, what is enlightenment, we see that Kant formulated one of the main parameters of modernism, through his emphasizing the subject and freedom. The subject is a founding element both in the
\end{abstract}

\footnotetext{
1 Prof. Dr., Ankara Hacı Bayram Veli Üniversitesi, İletişim Fakültesi, himmet.hulur@hbv.edu.tr, https://orcid.org/0000-0002-5863-4976.

2 Dr. Öğretim Üyesi, Ankara Hacı Bayram Veli Üniversitesi, Edebiyat Fakültesi, ufuk.bircan@hbv.edu.tr, https://orcid.org/0000-0003-0644-2769.
} 
basis of enlightenment and modernism. The subject provides the sine qua non opportunity for an independent endeavor of understanding and thinking. Through the subject's finding an historical possibility in such a way, we see the emergence of the philosophical grounds of modernism as well as the coming up of the standards for modernist scientific and aesthetical assessments. In this article, Kant's views on the enlightenment and modernity are scrutinized on the basis of Kant's own texts; the main contemporary echoes of these views are remarked and, in this context, Michel Foucault's evaluations are specifically taken into consideration.

Keywords: Immanuel Kant, Enlightenment, Modernity, Subject, Freedom, Actuality.

\section{Giriş}

Immanuel Kant'ın 1784'te kaleme aldığı “Aydınlanma Nedir? Sorusuna Yanıt” başlığını taşıyan metni aydınlanmayı hem bireysel ve toplumsal bir çıkış yolu olarak ele almakta hem de tarihsel bir olgu ve süreç olarak konumlandırmaktadır. Kant'ın söz konusu metni, günümüze kadar önemini sürdüren aydınlanmayı anlama çabalarında en temel başvuru kaynağı olarak görülmüsstür. Kant'ın bu metni aynı zamanda modernlikle ilgili yaklaşımlar açısından da son derece önemlidir. Bunun nedeni, tarihsel bir olgu ve süreç olarak aydınlanmanın modernlik tarihinin önemli bir parçası olmasıdır. Yine de aydınlanma ve modernlik her zaman bir arada var olmayabilir. Aydınlanma daha çok entelektüel tutumlarla ilişkiliyken, modernliğin karşıllı bulduğu alan yaşam biçimidir. Aydınlanma düşünme pratiği olarak gerçeklik bulurken, modernlik yaşam teknolojileri tarafından belirlenmektedir. Her ikisi de birer süreç olarak Avrupa tarihinde az çok uyumlu bir bütünlüğü oluşturmalarına karşın, sonradan modernleşen toplumlarda ikisi arasında esaslı bir gerilimin var olduğundan söz edilebilir. Modernlik yaşam teknolojilerinin özel bir biçimiyle birlikte, özellikle kent yaşamının gelişkin ve baskın yapısı içinde imkan bulduğu halde, bu durum aydınlanmanın modernlikle uyumlu bir biçimde gelişmesini sağlamayabilir.

Aydınlanma baştan beri fikir ayrılıklarını yansıtan bir kavram olmasına karşın son dönemlerde özellikle modernlik ve postmodernlikle ilgili literatürde disiplinlerarası bir ilginin odağı haline gelmiş, fikirsel yönelimlerdeki ayrılığın nedeni olarak işlev görmüştür. Aydınlanma ve modernliğin ne olduğu ve nasıl anlaşılması gerektiğini ele alan bu tartışmalarda postmodernlikle postaydınlanma, modernlikle aydınlanma karşısında bir arada anılmaktadır. Elbette bu ikisi arasındaki karşıtlıkla açıklanamayacak, iki taraftan biriyle kendisini sınırlandırmayan bakış açıları da önemli bir etki alanına sahiptir. Ancak benimsenen kuramsal tavır ne olursa olsun Kant'ın metinleri aydınlanma ve modernlikle ilgili düşüncelerin temel çerçevesini belirlemektedir. Bu değerlendirmeler ışığında burada ilk olarak Kant'ın Aydınlanmanın ne olduğu sorusuna verdiği cevabının yanısıra Fransız Devrimi hakkındaki düşüncelerini aktardığı metni ayrıntılı olarak ele alınmakta, daha sonra Kant'ın görüşlerinin bir yankısı olarak Foucault'nun bu metinlerle ilgili tutumuna ve yorumlarına aynı genişlikte yer verilmektedir. Ayrıca, her iki düşünürün yazılarından hareketle aydınlanma ve modernlik hakkında değerlendirmeler yapan Habermas ve Chatterjee'nin görüşleri dikkate alınmaktadır. Bunlara ek olarak, Kant'ın görüşleri ve bu görüşlere yönelik tepkiler temelinde ileri sürülen yakın geçmişteki bakış açıları, aydınlanma ve modernlik sorunsalının çerçevesi belirlenmeye çalışılmaktadır. Kısaca bu çalışma, Kant’ta aydınlanma ve modernlikle ilgili temel metinleri anlama çabasını yansıtan ve aydınlanma ve modernlik problematiğinin bu temel metinlerdeki ortak paydasını saptamaya çalışan mütevazi bir çaba olmayı amaçlamaktadır.

\section{Kant’ta Aydınlanma ve Modernlik Sorunsalı ve Günümüzdeki Yankıları}

"Aydınlanma Nedir? Sorusuna Yanıt" başlıklı yazısında Immanuel Kant, aydınlanmayı insanın kendi kabahatiyle içinde bulunduğu ergin olmamadan kendi çabasıyla kurtulması olarak görür. İnsan bu yetersizlikten kendi doğasında bulunan aklını kullanarak ya da düşünme cesareti göstererek kurtulabilir. Düşünme cesareti gösteren insan ergin olmama durumundan çıkarak aynı zamanda başkalarının yönlendirmesinden kurtulur. İnsanın yetersiz olması, kendi doğasında bulunan akıl yetisini kullanmaması, böylece kendisini başkalarının yönlendirmesi demektir. $\mathrm{Bu}$ nedenle aydınlanmanın temel şartı aklı kullanma cesareti göstermektir (Kant, Practical 17). Ergin olmama veya yetersizlik insanın içinden çıkması gereken bir durumdur, çünkü insanın doğuştan sahip olduğu yetenekler bu durumdan çıkmasını sağlayabilir. 
Aydınlanma bireysel bir çabayı gerektirdiği kadar bireyin dışındaki koşullarla da ilişkilidir. Düşünme cesareti göstermemeyi ergin olmama veya aydınlanmama olarak gören Kant'ın bu düşüncesi temelinde Aydınlanma döneminden önceki dönemlerde ergin olmayış veya yetersizlik hakimdir. $\mathrm{Bu}$ dönemlerde insan kendi doğasında bulunan aklı kullanmaya ve düşünmeye cesaret etmemiştir. $\mathrm{Bu}$ açıdan, aydınlanma aynı zamanda tarihsel bir gelişmedir. Düşünmeye cesaret etmek her şeyden önce insanın bir özne olarak tarih sahnesine çıkmasıdır. Kant, tarihsel koşulların aydınlanmanın önünde engel oluşturduğuna, insanın aklını kullanmasının, başkalarının yönlendirmesinden kurtulmanın zorluklarına değinmekte, insanın içinde yaşadığı koşulların aklını özgürce kullanmasını engellediğini dile getirmektedir. $\mathrm{Bu}$ anlamda, içinde bulunduğu güçlükleri aşarak aklını kullanma cesareti gösteren çok az insan olduğunu düşünen Kant (Practical 18), özgür bir kamusallık mevcut olduğunda bağımsız düşünürlerin bireyleri akıllarını kullanmalarını engelleyen boyunduruklarını çıkarmaya çağırmaları vasıtasıyla kitlenin aydınlanmasının mümkün olduğunu ifade etmektedir. Bununla birlikte, bireylerin boyunduruk altında kalmalarını isteyenler, bundan çıkar sağlayanlar, onlara koruyuculuk yapmak isteyenler de bulunmaktadır. Bütün bunlarla birlikte, insanların akıllarını özgürce kullanmalarının önündeki engeller birdenbire ortadan kalkmayacağı için kamunun aydınlanması ancak zaman içinde yavaş yavaş gerçekleşebilir.

Bireyin kendi aklını özgürce kullanarak aydınlanmasının toplumu ve kamuyu ilgilendiren daha kapsamlı bir olgu olarak aydınlanma için sadece ifade özgürlüğü gereklidir. Aklın kamusal olarak özgürce kullanılması, ifade özgürlüğünün önündeki engellerin azalmasına bağlıdır. Akıl ancak kamusal olarak özgür bir şekilde kullanıldığında aydınlanma gelişip güç kazanabilir. Ayrıca Kant, aklın kamusal ve özel kullanımları arasında ayrım yapar ve aydınlanmanın aklın kamusal kullanımıyla gelişeceğinin altını çizer. Kant (Practical 18-19) bu düşüncelerini ifade ederken aklın kamusal ve özel kullanımını çeşitli örneklerle açıklamaktadır. Bir araştırmacı veya bilim insanının tüm okurları ve izleyicileri karşısında aklını kullanması aklın bu türden bir kamusal kullanımına işaret eder. Ancak belirli bir görev yaparken ve belirli kamusal sorumlulukları yerine getirirken, örneğin vergi öderken aklın özgürce kullanılmasından söz edilemez. Yine örneğin bir papaz dini görevlerini dikkatli bir şekilde yerine getirirken aklını özgürce kullanması beklenmez, ancak kurallarla belirlenen görevlerini yapmanın dışında insanlara din adamı olarak seslenirken veya yazarken aklını özgürce kullanabilir ve kendi dini görüşlerini aklını özgürce kullanarak anlatabilir. Diğer görevlerde de insanlar görevle ilgili sorumlulukları dışında kendi akıllarını özgürce kullanabilirler. Papazın kilisedeki görevi veya bir başka görevlinin kendi görevleri dışında akıllarını özgürce kullanmasının önündeki birtakım kısıtlamalar olsa da bu kısıtlamalar zaman içinde yavaş yavaş azalarak evrensel aydınlanma daha fazla imkân bulacaktır. Özellikle dinsel konularda halkın kendi aklını özgürce kullanmasının kısa zaman içinde gerçekleşmeyeceği ancak eğilimin aydınlanma doğrultusunda olduğu ve dinsel konularla ilgili aydınlanmanın önündeki engellerin yavaş yavaş ortadan kalkacağı öngörüsünde bulunmaktadır.

İnsanın kendi aklını özgürce kullanmasının önündeki engelleri dikkate alan Kant kendi döneminin henüz aydınlanmış bir çağ olmadığını fakat aydınlanmaya giden bir çağ olduğunu ifade etmektedir. Özellikle dinsel konularda insan kendi aklını başkasının kılavuzluğu olmadan giderek daha fazla kullanacak, böylece insanın kendi suçuyla içine düştüğü ergin olmayış durumundan kurtulması gerçeklik bulacaktır (Kant, Practical 21). Bunun yanında, bilim ve sanat konularında koruyuculuk yapma yöneticilerin çıkarına değildir, bu konularda yurttaşların akıllarını özgürce ve herkese açık kullanmalarının bir sakıncası olmadığı gibi, yurttaşların herkese açı düşüncelerin alınması yasa yapılacağı için yasaların daha iyi olmasını sağlar. Aydınlanmış bir yönetici, yurttaşların düzene uymalarını talep etmesinin yanında onların istedikleri konular üzerinde özgürce düşünmelerini teşvik eder. Kant, özgür düşünme ve eylemenin yönetimlerin ilkelerini zaman içinde daha fazla etkileyeceğini bu durumun ise insan onuruna daha fazla uygun düşeceğini belirtmektedir (Kant, Practical 22).

Yukarıda değinildiği gibi Kant, "Aydınlanma Nedir? Sorusuna Yanıt" adlı metinde aydınlanmanın tarihsel ilerlemenin bir parçası olduğu fikrine yer vermiştir. Kendi zamanını aydınlanmanın bir başlangıcı olarak görmüş ve zaman içinde aydınlanmanın önündeki engellerin azalacağını öngörmüştür. Ayrıca Kant (The Conflict 142), "Felsefe Fakültesinin Hukuk Fakültesiyle Çatışması" başlıklı metninde "insan ırkı sürekli olarak ilerlemekte midir?" sorusunu sormakta ve bu 
sorunun, insanın biyolojik yönünü dikkate alan doğal tarih açısından değil, yeryüzünde bulunan insanların tümü dikkate alan ahlak tarihi açısından cevaplanması gerektiğini belirtmektedir.

Kant, insan ırkının bir bütün olarak ilerlediği, ahlaki olarak daha iyi hale geldiği düşünüldüğünde, bu ilerlemenin doğrudan tecrübeyle anlaşılamayacağını belirtir (Kant, The Conflict 149). Bununla birlikte, "insan 1rkının iyiye doğru ilerlemesinin nedeni olan insan yeteneği ve eğilimine işaret eden bir olayın" bulunması gerektiğine, "bu nedenle, böyle bir nedenin varlığına ve zamanla sınırlanmaksızın bu nedenin insan ırkında etkili oluşuna işaret eden, iyiye doğru ilerlemenin kaçınılmaz bir sonuç olarak çıkarılmasına izin veren bir olayın aranması gerektiği”ne dikkat çeker. Kant'a göre, "Bu sonuç, geçmişin tarihi için de geçerli kılınabilir (tarih sürekli ilerlemektedir), şöyle ki, bu olayın kendisi tarihin nedeni olarak değil, bütün olarak insan ırkının eğilimini kanıtlayan sadece bir gösterge, tarihsel bir işaret (signum rememorativum, demonstrativum, prognostikon) olarak anlaşılmak zorundadır" (Kant, The Conflict 151). Kant burada ilerlemeyi sadece belirli bir toplumun ilerlemesi anlamında tikel bir ilerleme olarak değil bütün insanlığın ilerlemesi anlamında evrensel bir ilerleme olarak görmektedir. Böyle bir ilerleme doğrudan insanın kendi doğasında bulunan bir eğilimin giderek daha fazla tarih sahnesinde kendisini göstermesi olarak kavranmaktadır.

Kant, kendi zamanında insan ırkının ilerleme yönündeki ahlaki eğilimini kanıtlayan bir olay olarak Fransız Devriminden söz eder ve ilerlemenin göstergesi olan olayın büyük eylemler veya mevcut yönetim yapısını altüst eden kalkışmalar gibi tarihsel olaylardan oluşmadığını ileri sürer. Kant'a (The Conflict 153) göre ahlaki ilerlemenin göstergesi, "büyük devrimler oyununda kendisini herkesin önünde açığa vuran, bir taraftaki aktörlere karşı diğer taraftakilere çıkara dayanmayan ancak evrensel olan bir duygudaşlık gösteren, araştırıldığında bu taraftarlıkları kendileri için dezavantajlı olabilecek seyircilerin düşünme biçimidir.” Burada Kant, bu düşünme biçiminin, evrenselliğiyle insan ırkının tümünün bir özelliğini, çıkara dayalı olmamasıyla insanlığın ahlaki bir özelliğini ifade ettiğini, insanların iyiye doğru ilerleme umutlarını artırmasının yanında kendisi de içinde bulunulan zamanda ilerleme olduğunu belirtir. Devrim, kendileri fiilen devrimde rol almayan seyircilerin kalplerinde, onların duydukları coşkuda yer edinmektedir. Bu coşku Kant'a göre "tehlike dolu olan devrimin bir ifadesidir, bu nedenle bu duygudaşlığın insan ırkındaki ahlaki bir eğilimden başka hiçbir nedeni olamaz." İlerlemenin göstergesi olarak devrimle birlikte ortaya çıkan ahlaki eğilim ve devrimin seyircilerde yarattığı coşkunun iki temel sonucu vardır. Birinci sonuç haklarla ilgilidir, ulusun vatandaşları iyi buldukları sivil bir yasaya sahip olmasıdır; ikincisi, ulusun yasasının kendisinin adil ve iyi olması ve saldırgan bir savaşa izin vermeyen ilkelere dayanmasıdır. İlerlemenin bir göstergesi olan Devrim'e insanların sempati duymaları ve coşku beslemeleri kendi içlerinde bulunan ahlaki eğilimle ilişkili olması, devrimin sonuçlarının tüm insanlık için geçerli olmasıdır. Devrim'le birlikte hakların yasalarla güvence altına alınması ve saldırganlığın engellenmesi insanların kendilerinde olan bir eğilimin cisimleştiğini görmeleri açısından dayatmacı veya buyurgan değildir.

Devrime duyulan bu sahici coşku her zaman hak kavramı gibi ideal ve saf ahlaki olana yönelir ve kişisel çıkara dönüştürülemez (Kant, The Conflict 155). "İlkece, aklın saf olarak sergilediği bir şey olmalıdır; yalnızca büyük ve çağ-yapan etkisi nedeniyle akıl onu, evrensel ve çıkarsız duygudaşlıkla onun başarısı için umutları ve onu gerçekleştirmeye yönelik çabaları selamlayan, insanlığı bir bütün olarak (non singularum, sed universorum) ilgilendiren, insan ruhunun onaylanmış görevi olarak sergiler" (Kant, The Conflict 157). Bu durum devrimin değil tüm önceki yasaları ortadan kaldıran bir yasa, savaşçı değil cumhuriyetçi bir yasa için mücadele etmeye yol açar. Kant, bu kazanımın artık geriye gitmeyeceğini öngörür. $\mathrm{Bu}$ olgunun insan doğasındaki iyiye yönelişin bir eğilimini ve yeteneğini açığa çıkardığı için unutulmayacağını, doğanın ve özgürlüğün içsel hak ilkesiyle uyum içinde insan ırkında birleştiğini göstermektedir. Devrim ve ulusal yasa başarısız olsa bile bu olay insanlığın çıkarlarıyla bütünleştiği ve etkileri dünyanın her tarafına yayıldığı için gücünden hiçbir şey kaybetmeyecektir. Dolayısıyla Kant, en sıkı kuram açısından geçerli olacak önermeyi şu şekilde ifade etmektedir: "İnsan 1rkı her zaman daha iyiye doğru ilerlemiştir ve bundan sonra da aynı şekilde ilerlemeye devam edecektir" (Kant, The Conflict 159). Dünya üzerindeki tüm insanlar yavaş yavaş ilerlemeye katılacaklar ve bu ilerlemeyi geriye döndürecek köklü bir değişim olmayacaktır. Bu süreçte kitlelerin eğitilmesi kitlelerin aydınlanması açısından önemli bir rol oynayacaktır (Kant, The Conflict 161). İnsanın iyi yöndeki çabalarının insanlığa sağlayacağı yararlar gitgide artacak, insanın ahlaki eğilimi giderek daha fazla gerçeklik bulacaktır (Kant, The Conflict 165). Devrim insan doğasındaki 
ahlaki eğilimin bir sonucu olarak insanın tarihteki ilerlemesini yansıtan ve tüm insanlığı temsil eden evrensel bir olay olarak ortaya çıkmıştır. Devrimle birlikte ortaya çıkan kazanımlar geri döndürülmesi mümkün olmayan kazanımlardır çünkü insanlığa dışarıdan dayatılmış haklar ve ödevleri değil insanın içsel özellikleri olarak ortaya çıkmışlardır.

Kant'ın Aydınlanma Nedir? sorusuna verdiği cevapları ve Fakültelerin Çatışması başlığı altında geliş̧irdiği düşünceleri ele alan Michel Foucault'nun görüşlerine burada bir ölçüde ayrıntılı olarak değinmekte yarar bulunmaktadır. Foucault'ya (Özne 162-164) göre Kant'ın ele aldığı Aufklärung sorusu felsefi düşüncede Kant'la sinırlı olmayan ancak yeni türden bir sorun, güncellikle ilgili bir sorundur. Ayrıca Kant'ın bu soru kapsamına giren konuları başka metinlerde de ele almıştır. Ancak Kant, başka metinlerinde tarihsel süreçler ve bu süreçlerde etkili olan teleolojik ilkeleri incelemiş olmasına karşın, Aufklärung hakkındaki metni diğerlerinden farklı bir içerik taşımaktadır. Diğer metinlerinde ilkelerin teleolojik işleyişini, köken sorunu ve gerçekleşme sorunu düzeyinde doğrudan ele almaz. Aydınlanma nedir sorusuna verdiği cevapta ise temel soru şimdiki zamanla ve güncellikle ilintilidir: "Bugün neler olup bitmektedir? Şu anda neler olup bitmektedir? Ve hepimizin kendimizi içinde bulduğumuz ve halen yazmakta olduğum şu anı tanımlayan bu 'şimdi' nedir?" Şimdiki zamanı ele alan başka düşünürlerde örneğin Descartes da şimdi doğrudan ele alınmamış felsefi bir değerlendirmenin bir parçası olarak şimdiye değinilmiştir. Kant ise doğrudan şimdinin ne olduğuyla ilgili bir tartışma ortaya koymakta ve felsefi düşünme açısından şimdiki zamanda anlamlı olanın ne olduğunu sorgulamaktadır. Kant bu soruyu cevaplarken hem bir unsuru hem de bir aktörü olduğu bu süreçte kendisinin de nasıl bir rol oynadığını ortaya koymaktadır. Başka bir ifadeyle Kant'ın cevabında şimdiki zaman felsefi bir olay olarak ortaya çıkmaktadır. Filozof şimdiki zamana aidiyetini sorgularken bunu belirli bir insan topluluğuna aidiyet sorunu olarak değil "belirli bir 'biz'e, insanın kendi güncelliğinin karakteristik özelliğini yansıtan bir kültürel bütünlükle ilişki içinde olan bir bize ait olma" sorunu olarak irdelemektedir. Filozofun kendisinin de ait olduğu şimdiki zamanın bir irdelenmesi olarak "felsefe, felsefeyi modernliğin söylemi ve modernlik üzerine söylem olarak" düşünmemizi sağlayabilir.

Foucault (Özne 164-166), Kant'ın metninde modernlik sorununa yaklaşımın yeni bir biçimde ortaya çıktığını belirtir. Kant'a kadar modernlik Antikçağ ile modernlikten oluşan iki ayrı kapsamda reddedilmesi veya kabul edilmesi gereken bir otorite sorunu olarak ele alınırken Kant, modernlik sorusunu "insanın kendi güncelliği ile" ilişsisi olarak irdelemektedir. Kant'ın metni, kendi güncelliğini, güncelliğin anlamını ve güncellik içerisinde izleyeceği eylem tarzını dikkate almaktadır. Yani güncelliğin ne olduğu, anlama geldiği ve güncellikten söz edenin ne yaptığı bu yeni sorgulama biçiminin odak noktasını oluşturmaktadır. Modernliğin soybilimi açısından bakıldığında Kant'ın metni "daha geniş kapsamlı bir tarihsel sürecin parçasını" oluşturmaktadır. Bu süreçte Aufklärung kendisini adlandıran, tarihsel akış içerisinde kendisini konumlandıran ve yapması gerekenleri belirleyen "kendi bilincine varmış olan kuşkusuz çok özel bir kültürel süreçtir”. Aufklärung kendisini konumlandırdığ1 tarihsel süreç içerisinde kendi kurallarını belirleyen ve karşılaştığı "bilgi, cehalet ve yanılsama biçimleri karşısında" nasıl davranacağını ifade eden kendisini düşünce tarihi içerisinde etkili olan bir olay aracılığıyla isimlendiren ilk dönemdir. Kendi güncelliğini sorgulamak on sekizinci yüzyılın sonuna doğru ortaya çıkan modern felsefenin temel özelliklerinden biridir. Kant 1784'te kendisine yöneltilen “Aufklärung nedir?" sorusunu 1798'de "Devrim Nedir?” sorusu bağlamında tekrar ele almıştır.

Kant, Devrim'le ilgili düşünceleri ilerleme ile ilgili düşünceleri kapsamında ortaya koymaktadır. Foucault (Özne 166-168) Kant'ın bu bağlantıyı kurarken, insanlığın sürekli ilerlemesinin mümkün olup olmadığı, mümkünse bu ilerlemenin gerçeklikteki yansımalarının nasıl gösterileceği konusundaki fikirlerinin önemini vurgulamaktadır. Kant, sürekli ilerlemenin mümkün olduğunu tarihte meydana gelen olaylarla göstermek gerektiğini düşünür. Ayrıca ilerlemeyi mümkün kılan nedenin insanlığın tümünün ilerlemesine yol açması gerektiğini belirtir. Kant, Devrim'i insanlığın tümünün ilerlemesine bir işaret değeri taşıyan bir olay olarak sunmaktadır. Bunun yanında Kant'a göre "ilerlemenin hatırlatıcı, kanıtlayıcı ve gelecekle ilgili işaretlerini aramamız gereken yer büyük olaylar değil, çok daha görkemli, gözle daha çok daha zor görülen olaylardır", bunu anlamadan şimdiki zamanı çözümlemek mümkün değildir. Kant'a göre önemli olan, Devrim'in sağlam yapıları sarsan boyutu değildir. Dolayısıyla Devrim'in "hatırlatıcı, kanıtlayıcı ve geleceğe ilişkin yargı bildirici 
özelliğe sahip olmasını sağlayan şey, devrimci dramanın kendisi olmadığı gibi devrimci serüvenler ya da onun beraberinde getirdiği birtakım jestlerin oluşması da değildir”. Devrim'in önemi kendileri derimde yer almayan ve onu seyredenlerin ondan nasıl etkilendikleridir. Özetle "ilerlemenin kanıt1, devrimci altüst oluş değil, seyirciler üzerinde bıraktığı etkidir”.

Foucault'nun (Özne 169-170) ifadeleriyle Kant açısından devrimin başarılı olup olmaması ilerlemenin bir işareti değildir. Bunun yanında ilerlemenin işareti devrim etrafındaki coşkulu bir eylem birliğidir. Devrime fiili olarak katılmayanların ve onun aktörü olmayanların kafalarından geçenler ve devrimle kurdukları ilişki devrimin kendisinden daha önemlidir. İnsanlıktaki ahlaki eğilim kendisini devrime duyulan coşkuda gösterir. Bu eğilim ise birincisi "bütün insanların, kendilerine uygun düşen siyasi Anayasayı; ikincisi kendi ilkeleri temelinde her türlü saldırganlıktan uzak durduğu ölçüde hukuk ve ahlaka uygun bir siyasi Anayasa ilkesinde" kendini gösterir. İnsanlığın böyle bir Anayasayı benimsemelerinin göstergesi devrim coşkusudur. Bu açıdan "insanların özgürce seçtikleri siyasi Anayasa ile savaştan uzak duran bir siyasi Anayasanın, aynı zamanda Aufklärung olduğu" açıklığa kavuşmuş olur. Böylece insanların kendi seçtikleri Anayasa saldırgan bir savaşın önüne geçecek ve ilerleme artık sorgulanmayacaktır.

Devrimden sonra her şeyin eski duruma dönme riski olsa da devrim gelecekteki ilerlemenin sürekliliğini sağlayacaktır. Bu açıdan Foucault (Özne 171), Aufklärung nedir? ve Devrim nedir? sorularıyla Kant'ın kendi güncelliği sorununu ifade ettiğini ayrıca bu soruların iki yüzyıl boyunca modern felsefede önemli bir yer tuttuğunu belirtmektedir. Bu nedenle Foucault'nun ifadesiyle Aufklärung "hem Avrupa modernliğini başlatan apayrı nitelikteki bir olay olarak hem de aklın tarihinde, rasyonalite ve teknoloji biçimlerinin, bilginin özerkliği otoritesinin gelişme ve yerleşmesinde kendini göstermiş kalıcı bir süreç olarak, bizim için salt düşünce tarihinin bir episodundan ibaret değildir. Aufklärung, on sekizinci yüz yıldan beri düşüncelerimize nüfuz etmiş felsefi bir sorundur".

Foucault (Özne 172) Aufklärung nedir ve Devrim nedir şeklindeki iki sorunun bugün bizim kendi günceliğimizin ne olduğu sorusuna yanıt verirken de önemini koruduğunu ifade eder. $\mathrm{Bu}$ bağlamda Kant, modern felsefede varlığını sürdüren iki önemli kültürel geleneğin temellerini oluşturmuştur. Bir yandan doğru bilgiye imkân veren koşulları ele alan felsefe geleneğinin ve buna bağlı olarak modern felsefedeki hakikatin analitiğinin temelini atmıştır. Diğer yandan ise Kant, Aufklärung ve devrim hakkındaki metinlerinde çağdaş felsefedeki başka türden eleştirel bir sorgulamanın, "güncelliğimiz nedir?" sorusu üzerinden öncülüğünü yapmıştır. Bu sorgulamanın kapsamına aldığı, "bir hakikat analitiği değil; şimdinin ontolojisi, kendimizin bir ontolojisidir". Foucault, kendisinin Hegel, Nietzsche, Max Weber ve Frankfurt Okulunun dâhil olduğu eleştirel düşünce geleneği içinde görmektedir.

Foucault'ya (Özne 174-175) göre Kant'ın Aufklärung sorusunu ortaya atış1, Hıristiyan geleneğinde bu sorunun ele alınma biçiminden farklıydı. Daha özel olarak o zamana kadar içinde bulunulan zamanın düşünülmesi, "dünyada ona ait olunan bir çağ", "işaretleri algılanan bir olay" veya "tamamlanmanın gün doğumu" olarak kendini göstermekteydi. Oysa Kant Aufklärung'u negatif bir şekilde "çıkış yolu” olarak ileri sürmüştür. Foucault (Özne 176) Kant'ın Aufklärung sorusuna cevap verdiği metinde güncelliği açımlamayı amaçladığını, bugün ile dün arasındaki farklılığı ortaya çıkarmaya çabaladığını, "şimdiyi, bir bütünsellik veya gelecekteki bir tamamlanma" olarak görmediğini vurgular. Aydınlanmanın bir çıkış yolu olması, insanın ergin olmayıştan ergin hale gelişi, böylece irade ve aklının başka birinin otoritesi altında bulunmaktan kurtuluşu olarak ifade edilir. Çıkış, mevcut bir süreç olmanın yanında bir görev ve yükümlülüktür. İnsan ergin olmama durumuna kendi suçuyla girdiği gibi bu durumdan kendi çabasıyla çıkabilir.

Diğer taraftan Foucault (Özne 177), aydınlanma sürecine yeryüzündeki tüm insan türünün mü girdiği yoksa insanlığı oluşturan şeyin mi değişime uğradığı konusunda Kant'nn belirsiz olduğunu belirtir. Kant açısından insanlığın ergin olmayıştan çıkışı "hem manevi ve kurumsal hem de etik ve siyasal niteliklidir". Buna karşın, Foucault'nun (Özne 179) görüşleri çerçevesinde Kant'ın aklın kamusal ve özel olmak üzere iki türlü kullanımı arasında yaptığı ayrım aydınlanma sürecinin nasıl işleyeceği konusuna belirginlik getirir. Aklın kamusal kullanımı özgür, özel kullanımı ise itaatkâr olmalıdır. İnsanın toplumda oynadığı rollerde, aldığı görevlerde ve yaptığı işlerde aklını özel olarak 
kullandığı için özgürce kullanması beklenmez. Fakat makinenin bir dişlisi olarak değil de topluluğun bir üyesi olarak aklını özgür ve herkese açık bir şekilde kullanması gerekir. Aklın, "evrensel, özgür ve kamusal kullanımları" bir arada bulunduğunda Aydınlanmadan söz edilebilir. Bu anlamda, bireylerin akıllarını özgürce kullanabilmeleri, özgürlügün önünde hiçbir engelin çıkarılmamasına bağlıdır. $\mathrm{Bu}$ nedenle aklın kamusal olarak özgürce kullanımının siyasi olarak güvence altına alınmasını, bir sözleşmenin varlığını gerektirir. "Özerk aklın kamusal kapsamda ve özgürce kullanılması, itaat etmek gereken siyasi ilkenin evrensel akı1la uyumlu olması koşuluyla, itaati sağlamanın en iyi güvencesi olacaktır". Bu bağlamda, Foucault'ya (Ö̈ne 180) göre, Kant, bir taraftan aklın özgürce kullanımını meşru kılan koşulların, diğer taraftan aklın meşru kullanım ilkelerinin belirginleştirilmesini gerekli görmüştür. Aydınlanmayı zamana hâkim olan eğilim olarak gören ve insanlık tarihinin erginlik ya da yetişkinlik çağına girdiğinin altını çizen Kant bu süreç içinde bireyin sorumluluğunu da vurgular. Foucault'ya göre Kant'ın Aufklärung sorusuna yanıt verdiği metin, "bir filozofun kendi yapıtının bilgiyle (connaissance) bağlantılı olarak anlamını, tarih üzerine düşünmeyi ve yazdığı ve yazmasına neden olan tikel anı bu şekilde, yakından ve içeriden ilişkilendirmesinin ilk örneğidir." Kant'ın bu metninin yeni ve farklı olan yanı, bugün üzerine düşünmesi, felsefenin güncelliği üzerine düşünmesidir. Burada aynı zamanda modernliğin tutumu olarak adlandırılabilecek bir hareket noktası da bulmaktayı.

Pre-modernlikle post-modernlik arasına yerleştirilen modernliğin bir çağ olarak Aydınlanmanın bir devamı mı olduğu yoksa ondan kopuş mu gösterdiğinin önemli bir soru olduğunu belirten Foucault (Özne 181), Kant'in Aufklärung'la ilgili metninde modernliğin bir dönem olmaktan ve pre-modern ve post-modern çağlardan ayırmak yerine bir tutum olarak görülebileceğini ve modernlik karşıtı tutumlarla nasıl mücadele ettiğinin anlaşılması gerektiğini dile getirir. Foucault'nun burada tutumdan kastının, "güncellikle kurulan bir ilişki kipi, bazı insanların yaptığı gönüllü bir tercih; nihayet bir düşünme ve hissetme tarzı, aynı zamanda bir aidiyet ilişkisini gösteren ve kendisini bir görev olarak sunan bir eyleme ve davranma biçimi” olduğunu ifade etmektedir.

Modernlik tutumunu Baudelaire'e başvurarak açımlamaya girişen Foucault (Özne 181) modernliği anlamada "zamanın süreksizliği bilinci"ni kapsayan "gelenekten kopuş, yenilik duygusu, zamanın geçip gidişi karşısında duyulan baş dönmesi"nin ön plana çıktığını belirtir. Baudelaire'in anlatımında modern olmak, şimdinin içinde ebedi olanın kavranması anlamında "bu sürekli hareketi" kabul etmede değil bu harekete karşı bir tutum benimsemekte kendini gösterir. Bu yönüyle modernlik, şimdinin kahramanlaştırılması tutumudur. Foucault'ya (Özne 182) göre Baudelaire'de modernliğin tutumu flanörlükten farklıdır. Flanör, geçici bir merakın ve andan geçici haz almanın peşindeyken modern insanın daha yüce bir amacı vardır ve sürekli olarak telaşlı bir arayış içindedir. "Modernliğin tutumu açısından, şimdinin yüce değeri, onu olduğundan başka türlü tahayyül etme ve onu yok ederek değil; onda olanı kavrayarak dönüştürme isteğinden ayrılamaz. Baudelaire'ci modernlik, gerçek olan şeye gösterilen aşın dikkatin, aynı zamanda hem bu gerçekliğe saygı gösterip hem de ona tecavüz eden bir özgürlük pratiğiyle karşı karşıya geldiği bir uygulamadır”. Foucault (Özne 184), Baudelaire'de modernliğin yalnızca şimdiyle değil kendilikle de kurulan bir ilişki biçimi olduğunu belirtir: "Baudelaire'e göre, modern insan kendini, kendi sırlarını ve kendi gizli hakikatini keşfetmeye çıkan insan değil; kendini yaratmaya çalışan insandır." Böylece zamanın akışıyla kendilik arasında kurulan ilişki modernliğin temel karakteristiklerinden biri olarak belirginleşmektedir.

İnsanın kendisini özerk bir özne olarak anlamasının köklerinin Aydınlanmada bulunduğunu belirten Foucault (Özne 184) bugün Aydınlanmayla bağın, tarihsel varlığımızın bir eleştirisi olan bir ethos'la sürdürebileceğini vurgulamaktadır. Foucault, bu ethos'un pozitif ve negatif olarak iki boyutu üzerinde durmaktadır. Foucault (Özne 185-186), tarihsel varlığımızın eleştirisini oluşturan ethos'un negatif boyutunun, ilk olarak, kendisinin “Aydınlanma'nın şantajı” dediği şeyin reddedilmesini kapsadığını belirtir. Aydınlanmanın günümüzdeki toplumsal ve kültürel süreçlerinin anlaşılmasında kaydadeğer bir yerinin olmasına ve önemini sürdüren bir felsefi sorunun temelini oluşturmasına karşın, bu durum Aydınlanma taraftarı veya karşıtı olmayı gerektirmez. Güncelliğimizi ve tarihsel varlığımızı belirli bir ölçüde Aydınlanma tarafından belirlenmiş olarak çözümlemeliyiz, ancak bunu yaparken Aydınlanma'nın iyi ve kötü taraflarını göz önünde bulundurmalıyız. Bu tür bir çözümleme, “"zorunluluğun fiili sınırları', yani kendimizin özerk özneler olarak oluşması açısından vazgeçilmez olmayan" noktalara yönelmelidir. İkinci olarak, tarihsel varlığımıza ilişkin eleştiride Aydınlanma ve 
hümanizmi birbirinden ayırmalıyız. Aydınlanma günümüzde de önemli ölçüde etkisini sürdüren olaylar ve süreçler bütünüdür. Hümanizm ise Hıristiyan hümanizminden Marxist hümanizme kadar çeşitli biçimlerde kendisini gösteren ve "kendi başına bir düşünce ekseni işlevi göremeyecek kadar esnek, çeşitli ve tutarsız" insan anlayışlarından oluşur. Burada, "kendimizi kendi özerkliğimiz içinde kesintisiz olarak yaratma ilkesi" yani Aydınlanmanın tarihsel bilinçle ilgili temel ilkesi hümanizmin karşısına çıkarılabilir. Kısaca, Aydınlanma ile hümanizm arasında her dönem farklı bir ilişki olduğu halde ikisi özdeş değil gerilimli bir ilişki içindedir.

Tarihsel varlığımıza ilişkin eleştiriyi oluşturan ethos'un pozitif içeriğini Foucault (Özne 188) üç ayrı kesitte açımlamaktadır. Birincisi, sınır-tutum olarak eleştiri, sınırların çözümlenişini ve sıkıca düşünülmesini kapsar. Aşkın olmayan ve metafiziğe dayanmayan bu eleştiri ereksel açidan soybilimsel, yöntembilimsel açıdan ise arkeolojiktir. "Bu eleştiri artık, evrensel değerlere sahip formel yapılar arayışında değil; bizi kendimizi oluşturmaya ve kendimizi yaptığımız, düşündüğümüz ve söylediğimiz şeylerin özneleri olarak tanımaya yönelten olayların tarihsel temeldeki sorgulaması olarak işleyecektir." Yani, sonsuz özgürlük çalışmasını mümkün kılmaya çalışan bu eleştiri, "düşündügümüz, söylediğimiz ve yaptığımız şeyleri eklemeleyen söylemleri tarihsel olaylar olarak" dikkate almasıyla arkeolojik, "olduğumuz gibi olmamak, yaptı̆̆ımızı yapmamak ve düşündüğümüzü düşünmemek" imkanına açık olmasıyla soybilimseldir. İkincisi, tarihsel varlığımızla ilgili eleştirinin "deneysel bir tutum" olması "gerçekliğin ve güncelliğin sınavından geçmesi gerekir". Ayrıca Foucault (Özne 189) bu tutumun, bütünsel ya da radikal projelerden uzak durmamıza, "ötesine geçebileceğimiz sınırların tarihsel-pratik düzlemde denenmesi ve dolayısıyla, özgür varlıklar olarak kendimiz"le ilgili çalışma yürütmemize imkan verdiğini belirtir. Foucault, tarihsel varlığımızın eleştirisini oluşturan ethos'un üçüncü özelliğini, kendimizi kısmi olanla ve yerelle sınırlandırmamızın daha genel yapıların yönlendirmesine kendimizi açı bırakma riskini taşıyıp taşımadığını sorarak açılamaya çalışır. Tarihsel varlığımıza ilişkin eleştiri, sınırlarımız ve sınırları aşma imkanımızı sorgularken düzensiz ve olumsal olanın yanında "bir genelliği, sistematikliği ve homojenliği ve temel soruları" barındırır.

Bat1 toplumlarında onsekizinci yüzyılda "dünya üzerinde teknik hakimiyet kurma kapasitesi”nin gelişimiyle birlikte bireylerin özgürlüklerinin eşzamanlı olarak büyüdügünü, özgürlük mücadelesinin kalıcı unsurlar oluşturduğunu belirten Foucault (Özne 190-191) kapasitelerin gelişiminin belirli biçimlerde iktidar ilişkilerini beraberinde getirdiğini vurgular. $\mathrm{Bu}$ açıdan, homojenlik, insanların yapıp etmelerini düzenleyen rasyonalite biçimlerini yani teknolojik boyutu ve pratik sistemler içinde bireylerin hareket özgürlüklerini yani stratejik boyutu dikkate almaktadır. Foucault'ya (Özne 191-192) göre pratik sistemler, şeyler üzerinde denetim kurmayı, başkalarıyla ilişkilerini ve insanın kendisiyle ilişkisini kapsar. Ayrıca bunlardan her biri diğerleriyle ilişki içindedir. Pratik sistem içinde bilgi, iktidar ve etik ekseni özgüllükleri ve bağımlılıkları açısından analiz edilmesi gerekir. Bu bağlamda "kendimize ilişkin tarihsel ontoloji" sistematikleştirme açısından şu sorulara cevap arar: "Kendimizi bilgimizin özneleri olarak nasıl kurduk? İktidar ilişkilerini kullanan ya da bu ilişkilere tabi olan özneler olarak nasıl kurduk? Kendi eylemlerimizin ahlaki özneleri olarak nasıl kurduk?" Tarihsel varlığımıza ilişkin eleştirel sorgulamalar, "bir çağ, bir pratikler ve söylemler bütünüyle ilgili olmaları" anlamında özel olsalar da Batı toplumlarında çağımıza kadar varlıklarını sürdürmeleri açısından genellik barındırırlar. Burada, "tarih-ötesi süreklilikler"in değil, belirli bir sorunsallaştırma biçimi açısından genellik gösteren soruların tarihsel tikelliklerinin altı çizilmektedir. Foucault (Özne 192), Aydınlanmanın şimdiye kadar bizi olgunlaştırmasa da Kant'ın Aydınlanmayla ilgili düşüncelerinin kendimiz ve güncelliğimizin sorgulanması açısından önemini koruduğunu vurgular. "Kendimize ilişkin eleştirel ontoloji... bir tutum, bir ethos, olduğumuz şeyin eleştirisi, hem bize dayatılmış olan sınırların tarihsel analizi hem de bu sınırların aşılmasının denenmesi olan bir felsefi yaşam olarak kavranmalıdır."

Kant'in Aufklärung ve Devrimle ilgili metinleri temelinde Foucalt'nun ortaya koyduğu görüşleri ele aldığı yazısında Jurgen Habermas (Taking 104) Foucault'nun son zamanlarında yaptığ1 bu değerlendirmelerin diğer eserlerinde ortaya koyduğu bilgi/iktidar eksenli kavrayıştan ayrıldığını ileri sürmektedir. Foucault'nun diğer eserlerinde daha farklı bir Kant bulunmaktadır. Foucault, diğer metinlerinde kendisini aydınlanma çizgisinden tümüyle ayrı bir yerde konumlandırırken, güncelliğin ontolojisi bağlamında kendisini aydınlanma geleneğinin ve kökleri Kant’a kadar uzanan eleştirel felsefenin bir parçası olarak sunmaktadır. Foucault, bu son dönem metinlerinde, metafizik mirası terk 
eden ve "anlamsız ve mevcut olmayana, salt rastlantısal ve geçici olana" odaklanan felsefenin öncüsü, kendi dönemine kadar hâkim olan metafizik felsefesini, bu "gizemli felsefeyi şimdinin bir eleştirisine dönüştüren Kant'1 çağdaş bir felsefeci olarak keşfeder." Habermas'a (Taking 106-108) göre Foucault, son eserlerinden biri olan bu ders metnine kadar disiplinsel iktidarın bir parçası olarak gördügü ve reddettiği bilme istencini bu ders metninde "korunmaya değer ve yenilenmesi gerekli eleştirel dürtü olarak" ele almasıyla "kendi düşüncesinin modernliğin başlangıcıyla bağlantısını kurmakta" ve "yıkabileceğini düşündüğü modernliğin felsefi söylemine" dahil olmaktadır.

Kimi yazarlar, Kant'ın aydınlanma hakkındaki görüşlerini, saf aklın eleştirisiyle ilgili düşüncesinin önemli bir parçası olarak değerlendirirler. Baghai'nin (143) ifadesiyle, “Aydınlanma en başta saf aklın aydınlanmasıdır, yani aklın açıklık kazanmasıyla birlikte akıl kendisini yönlendirebilir ve tüm kullanımlarında özerk olabilir. Bu, felsefi aydınlanmanın saf aklın eleştirisi (disiplin) ile bir ve aynı olması demektir... Akıl bu disiplinsel birliği vasıtasıyla kendisini kendi yasalarına dayalı olarak ve 'başkasının yönetimi olmadan' yönlendirebilir." Diğer taraftan Kant'ın saf akıl kavrayışına daha radikal eleştiriler de bulunmaktadır. Örneğin, Mack (31), Freudçu bir bakış açısından Kant'ın "saf" olarak düşündüğü aklın akıldışından oluştuğunu ifade etmektedir. Bu çerçevede, aydınlanmanın temeli olarak ileri sürülen saf aklın karakteri hakkında birbiriyle uzlaşmaz görüşler, Aydınlanmanın tarihsel önemine yönelik farklı değerlendirmelerin hareket noktasını oluşturmaktadır.

Kant'ın Aufklärung hakkındaki metni aydınlanmanın kendi üzerine düşüncesi olarak değerlendirilebilir. Aynı zamanda bu tür düşüncenin ilk örneklerinden biri olduğu için kendinden sonraki aydınlanma üzerine metinlerin dikkate aldıkları bir metin olmuştur. Bu anlamda Breackman'ın ifade ettiği gibi, "Kant'n metninde Aufklärung kendisinin bir muhasebesini yapar ve kendisini anlamaya ve açıklamaya çalışır. Buna ek olarak, metnin beyanları, açıkça özgür konuşan, kendi anlayışına yaslanan ve kolayca erişilebilir bir metin aracılığıyla büyük bir kitleye hitap eden bir entelektüelin beyanlarıdır". Metin, aydınlanma için bireyin özgür düşünmesi gerektiğini vurgular. Bunun yanında, özgür düşünceyi mümkün kılacak şekilde "bağımsız düşüncenin özgürce ve kısıtlanmadan ifade edilmesini" siyasal olarak teminat altına alınması da gereklidir. Buna karşın, Aydınlanma insanın doğasında bulunan kaçınılmaz bir eğilim olduğu için desteklenmeli ve ortaya çıkarılmalıdır (Breackman 286). Aydınlanmanın imkânı, insanın a priori olarak sahip olduğu ahlak yasasına sayg1 dolayısıyla insana sayg1 duygusunda bulunduğu (Ürek 24) düşünüldüğü için bu duygunun evrensel bir aydınlanmanın temeli olarak görülmektedir. Romore'un $(82,95)$ anlatımıyla, Kant'ın bu evrensel insanı, maddeciliğin tersine, insanı mekanik yasalara indirgemez ve "insan makine" imgesini kabul etmez. Bu bakış açısından, insanı makine olarak gören maddecilik, insanın kendine özgü içsel değerini ve onurunu reddeder. Bununla birlikte, Kant'ın tarihte sürekli ilerleme ve evrenselcilik fikrinin insan ırkının iyileştirilmesini amaçlayan tekno-biyolojik gelişmeleri kapsayan posthümanizmle bağlantısını kurmak da mümkündür. Bu bağlamda, Aquilina (130-131), Kant'ın görüşleri çerçevesinde aydınlanma sorunlarıyla posthümanizm arasında bir bağlantı bulunduğunu, Kant'ın, tarihsel gelişmenin yanında posthümanist fikirlerin gelişmesine de katkıda bulunduğunu ileri sürer.

Kant, pratik akıl kuramının devrimle bağlantılarını açıklamıştır. Bu bağlamda "Kant'ın dikkati siyasal eyleyenin ahlakiliğine odaklanmıştır. Aslında Kant siyaset ve ahlak arasındaki ilişkinin uyumlu bir kuramını geliştirmiştir. Kant, ahlak olmadan siyasetin insanların çirkin bir kibir kusuruna dayandığını ve bunun despotizm pratiğini içeriden cesaretlendirdiğini ileri sürmüştür” (Fehér 182). Kant'ın Aydınlanma anlayışı, bireyin hem özgür düşünmesini hem de düşüncesini özgürce kamusal alanda ifade etmesini gerektirmesi bakımından iki bileşenden oluşur (Flesichacker 177, 193). Birey kendi doğasında bulunan özgür düşünme yeteneğini harekete geçirmelidir. Ancak Aydınlanma sorunu bununla çözüme kavuşmaz. Kamusal alanda da özgür düşüncenin ifade bulması, engelle karşılaşmaması gerekir. Kant bunun için entelektüelin ve yöneticinin ödevini vurgular. Kant'a göre, entelektüelin ödevi aklın kamusal kullanımını sürdürmek, yöneticinin görevi ise "entelektüellere eserlerini sansür korkusu olmadan yayınlama hakkı vermek"tir (Mensch 192). Kant, "devlet cumhuriyetçiliği, temsili demokrasi ve rasyonel bireyciliği, kozmopolit bir demokrasiye doğru ilerlemenin işaretleri" olarak görür ve bu anlamda "tarihsel olayların görünen dağınıklığını insanlığın ahlaki ilerleme İdea'sı" temelinde çözüme kavuşturur (Abbinnett 202). En temelde, demokratik bir yönetimin Aydınlanmanın kamusal alanda sürdürülmesine imkan verir. Bu bağlamda Kant'ın 
Aydınlanma için bağımsız düşünceyi gerekli görmesi modern özerk birey fikriyle, aklın özgürce kamusal kullanımı yoluyla ifade özgürlügünü vurgulaması liberal siyasal düşüncenin temel görüşleriyle koşutluk gösterir (Cronin 51).

Kant'ın evrenselciliği, metafiziksel ahlak ilkelerini tüm rasyonel failler için geçerli saymasında yatmaktadır, buna karşın, bu evrensel ilkelerin uygulanmasında ve yerleştirilmesinde pratik antropolojik gerçekliği yani kültürel ve toplumsal koşulların çeşitliliğinin önemini kabul eder (Westphal 128). Bu bağlamda, Kant'ta aydınlanma anti-özcüdür ve kendisini sadece akılla sinırlandırmaz, "akıl ve deneyimi bir araya getirir." Bilgi hem deneyimden hem de akıldan gelir; deneyimle akıl uygulama alanı bularak önyargılarından temizlenir (Wilson 180). Daha özel olarak, evrenselci ahlak kuramcıları, topluluk ve ahlak değerlerini yok sayarak dünyada rasyonelleşmeyi hâkim kılmaya çalışan Avrupa emperyalizmini eleştirdikleri halde, Westphall'a göre Kant'ın ahlak ilkeleri, adalet ve erdemin yanısıra topluluk ve arkadaşlık değerlerini destekleyicidir $(128,145)$. Buna karşın, Dostal'ın ifade ettiği gibi Gadamer, Kant'ın Aydınlanmacı bireyciliğinin dayanışmayı ciddiye almadığını "tüm eserlerinde arkadaşlık olgusuna sadece bir sayfa ayırdığını" vurgulamaktadır (Dostal 348).

Gümümüzde egemen olan kültür biçimlerine ilişkin birçok değerlendirme modernliğin sonunu ilan eden bakış açılarıyla sunulmaktadır. Modernliği olduğu gibi modernliğe hısım olguları da -post ekiyle birlikte ifade eden ve tarihin modern aşamasının geçerliliğine kuşkuyla bakan bu yaklaşımlar akıl, özgürlük, demokrasi ve ilerleme gibi ilkelerini sarsmaya çalışmaktadır. Bu bakış açıları karşısında Habermas'ın temel tavrı, bu ilkelerin gerçekleştirilmesinde ortaya çıkan kusurların aydınlanmanın kendisinden kaynaklanmadığıdır. Habermas, modernliği köklü eleştirileri içeren postAydınlanmacı ve posmodernist bakış açılarının modern kültürle ilgili eleştirel değerlendirmelerinin birçoğuna katılmakla birlikte onların bu kültürü tümüyle yadsıyıcı görüşlerine katılmaz ve modernliğin Aydınlanma düşüncesinde temelleri bulunan ilkelerinin geçerliliğini koruduğunu düşünür. Habermas'a ("Modernity" 52-53) göre modern kültürün şimdiye kadar yoksullaştırılmış gündelik yaşamla daha farklı bir bağlantı kurması, "toplumsal modernleşme süreci başka kapitalist olmayan yönlere çevrilebildiğinde, ekonomik ve yönetsel sistemin özerk sistemsel dinamikleri tarafından halihazırda kısıtlanmış olan yaşam dünyasının kendi kurumlarını geliştirebildiğinde" mümkün olacaktır.

Modern dünyadaki toplumsal, politik ve entelektüel süreçleri Aydınlanma karşıtı görüşlere dayalı olarak rasyonel söylemin temellerini sorgulayan ve Aydınlanmacı öncü felsefi ve edebi metinleri yapısökümüne uğratan Derrida, Foucault, Vattimo ve Vrilio gibi düşünürler Nietzsche ve Heidegger'in eserlerinden etkilenmişlerdir. Aydınlanma karşıtı bu yaklaşımlar, rasyonel tarafsızlık anlayışının "öteki”ni akıldışı, olağandışı ve anormal olarak yaftalama yoluyla dışladığını ve baskı altına aldığını ileri sürerek aklın kendisinin akıldışına dayandığını göstermeye çalışırlar (Linker 337338). Buna karşın, Benson'a (87) göre postmodernistler aydınlanma geleneğini eleştirmek için kullandıkları özgürlük ve hak gibi kavramları aynı geleneğe borçludurlar. Aydınlanma geleneğini eleştirirken geleneğin düşüncemiz üzerindeki etkisini inkâr etmek kendimizi inkar etmektir. Ona göre bu tutum, geleneği de Kant'i da eleştirmeden kabul etmemiz anlamına gelmez.

Politik açıdan bakıldığında, modern dünyayı olumlayan "söylemlerin ahlaki içerikleri” ile mevcut toplumsal, siyasal ve ekonomik gerçeklik, başka bir ifadeyle "modernliğin değerleri ile modernleşmenin güçleri arasında bir gerilim" olduğunu belirten De Kadt'a (50) göre "modernliğin demokratik ve özgürleşimci vaadi, modern iktidar sistemlerinin anti-demokratik ve kısıtlayıcı doğası nedeniyle yerine getirilmemiş olmayı sürdürmektedir." Modern toplumlarda güçlü bir demokrasinin gelişimi piyasa, gözetim, denetim ve cebir yoluyla engellenmiştir. "Bir kimsenin kendisine tayin ettiği yasaya boyun eğme olarak özerkliğe ve özgürlüğe ilişkin Rousseaucu ve Kantçı modeller, iktidar yapıları ve karar alma süreçlerinin sıradan insanların ihtiyaçları ve dileklerine sınırlı bir duyarlılık göstermekle kalmadıkları, insanların bu ihtiyaçları ve dilekleri bilmelerini ve özgürce tanımlamalarını s1klıkla engelledikleri bir dünyaya pek uymaz."

Modernlik, "içinde sonralık deneyiminin daha önce görülmemiş derecede kaçınılmaz hale geldiği felsefe ve kültür tarihsel epistem"dir. Bu anlamda, Derrida'nın tabiriyle "paleonomy -yani 'yeni bir kavram sunmak için eski bir adı sürdürmek'-" olarak anlaşılabilir. Kültür ve felsefe açısından 
modernlik, Kant'ın Kopernikçi dönüş olarak adlandırdığı kapsamda yer almaktadır. Bu ise basitçe olgular dünyasının bilincin yetenekleri tarafından temsil edilmesini kapsayan eleştirel felsefe olarak, "akılla yüzleşmeyi amaçlayan aklın radikal öz-eleştirisinin bir biçimi olarak" daha önceki dogmatik ve kuşkucu felsefenin terk edilmesini gerektirir (Richter 29).

Avrupa'da onsekizinci yüzyılın, Aydınlanmayla ilgili olduğu kadar sanat, felsefe, ahlak, siyaset alanlarının tümünde eleştirel düşüncenin hüküm sürmesiyle bir Eleştiri Çağı olduğunu belirten Deligiorgi (2005: 14) aydınlanmayı bir kültür olarak nitelendirir ve yakın dönemde Avrupa Aydınlanmasına yönelik başlıca eleştirileri, görüşlerini modern kültür çözümlemesi temelinde ortaya koyan eleştirel kuram, postyapısalcılık ve çağdaş feminizmi temsil eden Adorno ve Horkeimer'in Aydınlanmanın Diyalektiği (2010), Foucault'nun Hapishanenin Doğuşu (2001) ve Gilligan'ın Kadının Farklı Sesi (2017) adlı çalışmalarına başvurarak değerlendirir. Deligiorgi'ye (160-161) göre bu eleştiriler, "mevcut toplumsal baskı, siyasal adaletsizlik veya ahlaki olgunlaşmamışlığın" Aydınlanma mirasıyla bağlantısını kurarlar. Bu bağlamda, Aydınlanmaya en radikal eleştiriyi geliştiren Adorno ve Horkheimer'ın bakış açısından "yirminci yüzyıl totalitarizmi, rasyonel ve özgür bir topluma yönelik aydınlanmış umutların saptırılması olarak değil, özündeki irrasyonellik ve öz-yıkımı gizleyen 'aydınlanmanın diyalektiği'” olarak ortaya çıkmıştır. Bu anlamda aydınlanma düşüncesi modern toplumdaki tahakküm biçimlerinin suç ortağı olmuştur. Foucault ise modern toplumlarda egemen olan iktidar ilişkileri konusundaki tarihsel çözümlemeler vasıtasıyla aydınlanmanın özgürlük ve ilerleme gibi nosyonlarının köklü bir sorgulamasına girişmektedir. Bu bağlamda toplumsal ve siyasal bir toplum tasarımını tümüyle reddetmektedir. Gilligan'ın feminist ahlaki bakış açısı, karmaşıklığı ve çoğulculuğu dikkate alan özen ahlakını Aydınlanma düşüncesinin bir parçası olan evrensel talepler içeren hak ahlakının karşısına koyar. Bu düşünürlerin hepsi "aydınlanma rasyonelliğini, araçsal ve hesaplayıc1, cezalandırıcı ve baskıc1, toplumsal cinsiyet yanlı ve monolitik" olarak görürler.

Diğer taraftan Piche (199) Kant'ın aydınlanma anlayışının odak noktasında genel olarak kültürün, özel olarak ise eğitimin bulunduğunu ileri sürer; bu bağlamda kültür "hem sorun hem de çözümün bir parçası"dır. Piche'ye (213-214) göre aydınlanma kültüre yönelik eleştirel hatta yıkıcı bir tutumu gerektirir, bu nedenle doğru terim aydınlanma kültürü değil kültürün aydınlanmasıdır. Cascardi'ye (10-11) göre, sadece bireyci kültür değil aynı zamanda Frankfurt Okulu'nun sözünü ettiği kitle kültüründeki şeyleşme ve rasyonelleşme, kapitalizmin meta ilişkilerinden uzaklaşarak artı değerin simüle edilmiş bir ekonomisine geçmesiyle "hiperestetik postmodern mekanın doğuşu"yla birlikte büyük bir dönüşüme uğramıştır. Medyanın merkezsizleştiği bu ortamda Nietzsche'nin edilgen bir seyirci olarak posttarihsel birey ve Baudrillard'ın yüzeyselliğin büyüleyiciliği nosyonlarında ifadesini bulan “yeni, postmodern kültürün kendi kendisini doğrulayan nihilizmi” olarak hüküm sürmektedir.

Kant'ın Aydınlanma Nedir? sorusuna verdiği yanıtı ve Foucault'nun bu yanıt bağlamındaki görüsslerini ele alan Partha Chatterjee, Kant'ın "Aydınlanma Nedir? sorusuna verdiği yanıtı günümüzde yeniden düşünürken uluslararası ilişkilerin özellikle sömürgecilik olgusunun dikkate alınması gerektiğini ve bu açıdan Foucault'nun bilgi pratikleri ve iktidar teknolojileri hakkındaki görüşlerinin önemini vurgular. Chatterjee'ye göre, Kant'in yanıtı, modern toplum felsefesinin en erken temsillerinden biri olmasına karşın, modernlik tarihi Batılı olamayan toplumlarda evrensel modernlik öngörüsünden farklı bir seyir izlemiştir. "Evrensel akıl ve kurtuluşu getirecek bir modernlikten söz eden Batılı Aydınlanma felsefecileri, son iki yüzyılda dünya tarihinin birçok barbarlığına tanık olan bizlere... asla ergin görünmez." Chatterjee Batılı olmayan çeşitli düşünürlerin yüzyıldan daha uzun bir süreden beri toplumsal ilerlemeyi değil gerilemeyi dile getirdiklerini, modern olmanın bizi modernliğin değerleri ve sonuçları hakkında belirli kuşkulara sevk ettiğini vurgular. Ona göre, modernlik tarihi sömürgecilik tarihinin ayrılmaz bir parçası olduğu için "evrensel bir özgür söylem alanı"nın bulunduğuna inanmak güçtür. "Bir şekilde başlangıçtan beri şu zeki tahminde bulunduk; modern bilgiler ile modern iktidar rejimlerinin yakın suç ortaklı̆̆ 1 açıkken evrensel modernliğin ilelebet tüketicileri olarak kalacak, asla üreticileri olarak ciddiye alınmayacağız" (Chatterjee 13-14). Chatterjee'nin burada ileri sürdüğüne benzer görüşlerin, Batı dışı toplumlarda aydınlanma ve modernlikle ilgili yaklaşımları ele alan sömürgecilik, sömürgecilik sonrası ve bağımsızlık ve Batı hegemonyası konusundaki literatürde geniş yankı bulduğu söylenebilir (Akça ve Hülür 274).

Modern toplumda iktidar rejimini, devletin buyrukları değil aklın ilkeleri yoluyla bireylerin kendi davranışlarını biçimlendirdikleri iktidar pratiklerinin oluşturduğunu ifade eden Chatterjee (19) 
özgürlük istencinin iktidara karşı direnme imkânı da sağladığını vurgulamaktadır. Ancak, özgürlük istencinin evrensel karşıllıklarını aramak yerine, hangi bağlamda ve koşulda kendisini gösterdiği, modernliğin hangi biçimlerde gerçeklik bulduğunun anlaşılması için önemlidir. Bu açıdan örneğin, bir zamanlar modernlik, Hindistanlıların öncelikle aydınlanmaları gerektiği ileri sürülerek Hindistan'ın sömürgeleştirilmesi için kullanılmıştır. Ancak, bir dönem sonra aynı modernlik mantı̆̆ı, "özgürlük hayali, iktidar arzusu, iktidara direnme" vasıtasıyla bağımsızlık idealinin bir parçası olarak ortaya çıktı. "İktidar ağının dışında modernliğin vaat edilmiş bir toprağı yoktur. Bu nedenle modernliğin taraftarı ya da karşı1tı olunamaz, sadece modernlikle baş etme stratejileri tasarlanabilir." Chatterjee'ye (20) göre, bu stratejilerin sabit bir biçiminden söz edilemez, kimi zaman yıkıcı olabilecekleri gibi kimi zaman da yararlı olabilirler. "Modernliğin dünya arenasında paryalar, dokunulmazlar olduğumuzu hatırlarız. Bizim için modernlik, raflarda sergilenen yabanc1 malların bulunduğu bir süpermarket gibidir: öde ve istediğini al. Orada hiç kimse modernliğin üreticileri olduğuna inanmaz." Bütün bunlar dikkate alındığında "Kant, Batı modernliğinin kurulma anında bugünü geçmişten kaçış yeri olarak gördüğü halde, bize göre kaçmamız gereken tam da şimdidir." Bu durum bizim için modernliğin Batı modernliğinden köklü bir şekilde farklı olduğunu göstermektedir. Batı egemenliği, Batı dışı toplumları modernliğin mağdurları haline getirdiği için bu toplumlarda modernliğin değeri muğlaklaşmaktadır. $\mathrm{Bu}$ belirsizlik, modernliğin taraftarı veya karşıtı olmaktan değil, tersine modernliği tesis etmek için kimi zaman "başkaları tarafından kurulan modernlikleri reddetme cesareti göstermemiz gerekliliği”’nden kaynaklanır. İçinde bulunduğumuz küreselleşme çağında bu cesarete daha fazla ihtiyaç duyulmaktadır.

Chatterjeee'nin Doğu-Batı, geçmiş-şimdi arasında kurduğu bağlantıların ve vurguladığı uyumsuzlukların işaret ettiği gibi, Aydınlanmaya ve modernliğe yönelik yaklaşımların, ülkelerin tarihsel mirasıyla kurulan felsefi irtibatla yakından ilişkili olduğu görülmektedir. Bu açıdan örneğin Dimitreva'nın (380) ifadesiyle, Rusya'da yeni-Kantçı felsefe bu ülkenin Batı'daki gibi bilimsel ilerleme ve toplumsal değişim yaşaması ve bunun felsefi bir açıklamayı gerektirmesi dolayısıla "Rus entelektüellerinin mistik-dinsel düşünceye karşı bilimsel temellere dayanan bir felsefeye ihtiyaç duymaları" sonucunda ortaya çıkmıştır. Diğer taraftan, Aydınlanma ve modernliğin tarafında ya da karşısında yer almadan tarihsel ve kültürel mirası daha farklı bir tarih okuması ve tarihyazımıyla anlamaya çalışan, Kant'ın Aydınlanmaya ilişkin yanıtını ve Foucault'nun ve Habermas'ın bu yanıta ilişkin görüşlerini Çin tarihyazımı daha özel olarak Konfüçyüsçü görüşler açısından inceleyen Zhang (4), Çin tarihyazımında Foucault'nun görüşleriyle koşutluklar bulunduğunu belirtmektedir. "Foucault'nun savunduğu 'sınır ihlali' deneyimi, Kant'ın 'aydınlanma ve devrim' ve 'özel ve kamusal kültür' diyalektiğinin ötesine geçmeyi amaçlamıştır.” Foucault'nun çalışmasının önemi, aydınlanma ve modernlik tarafından sesleri kesilen "aklın öteki tarafi"na, "akıldışı tarafı"na erişme çabasıdır. Bu bağlamda Raffnsøe, Thaning \& Gudmand-Høyer (10) "felsefi pratiği sınır aşma beklentisi olarak" gören Foucault'nun tefekkür biçiminin Kartezyan ve Hegelci felsefi tefekkürden ayrıldığını ileri sürerler. Zhang'a (7) göre hem Konfüçyüsçü hem de Foucaultcu tarihçiler tarihin şimdi için yazılması gerektiğini düşünürler; "insanlığın ilerlemesinin ve özgürleşiminin önemli bir metaforu olarak aydınlanma anlamını asla tek bir tarihsel gerçekleşimde tüketmemelidir: şimdinin daima değişen bağlamıyla ilişkili olarak insanlığın kendini anlaması sürekli kendisini yenilemektedir.” Bu ve benzer görüşlerin aydınlanma ve modernlik yorumlarının Batı egemenliğini besleyen evrenselci ve tekçi yorumlardan farklılaştığı görülmektedir.

Benzer şekilde Benson (88), Kant'ın farklı kültürlerin ahlaki sezgileri ve idealleri olabileceğine ihtimal vermediği halde, Foucault, tümüyle farklı kültür ve düşünce biçimlerinin imkanını gösterdiğini vurgular. "Kant'ın erginlik hakkındaki fikrinden çıkaracağımız ders şudur; yalnız bireyin asla kendisi için düşünmeyi ümit edemeyeceği gibi, bir etnik grup, bir ulus veya kültür olarak biz de kendi kültürümüz üzerine düşünemeyiz. Kendimizin ve anlayışımızın sınırlarını kavramayı öğrenmezsek asla ergin olamayız.” Bu bağlamda, bireylerin kendi sınırlarını tanımalarının kendi özgürlükleri açısından gerekli olduğunu, kendi kültürlerinin sınırlarını tanımaları ve kendilerininkinden farklı kültürlerin ve düşünce biçimlerinin mümkün olabileceğini kavramalarının aydınlanma sorununun temel bir boyutu olduğunu söyleyebiliriz. 


\section{Sonuc}

Bu çalışmada iki yüzyıldan daha uzun bir süreden beri Batılı düşünce biçiminin öncülük ettiği küresel bir bağlama yerleşen ve günümüzde önemini sürdüren aydınlanma ve modernlik sorunu, bu sorunları ele alan temel metinlere başvurularak anlaşılmaya çalışıldı. Kant'in Aufklärung'un ne olduğu sorusuna verdiği yanıttan oluşan metni aydınlanmanın kendi kendisini ele alan ilk metni olması nedeniyle bu metin üzerinde ayrıntılı olarak duruldu. Günümüzde kendini hissettiren başlıca kültürel ve toplumsal sorunların Kant'ın Aydınlanma problematiği çerçevesinde nasıl ele alındığı üzerinde duruldu. Ayrıca, modernliğin özellikle demokrasi ve ilerleme açısından Kant'ın düşüncesiyle ilişkisi ele alındı. Daha özel olarak Kant'ın, aydınlanmayı karakterize eden özgür düşünmeyi hem tarihsel bir gelişme hem de zaman ve mekan dışı bir gereklilik olarak ifade etmesiyle, aydınlanmayı evrensel bir hareket ve değer olarak kavradığı vurgulandı.

Aydınlanmanın ne olduğu, tanımı ve kapsamı konusunda klasikleşmiş ilk metni yazan Kant aydınlanmayı evrensel bir tarihsel süreç olarak görmesinin yanında, bir ödev olarak kavramıştır. Ona göre aydınlanma bir taraftan geçmiş dönemlerdeki kısıtlamaları ortadan kaldıran ve özgür düşüncenin önünü açan ve giderek güçlenecek olan tarihsel bir harekettir. Diğer taraftan ise aydınlanma ödev ahlakı gereği savunulması ve sürdürülmesi gereken bir değerdir. Yani Kant'a göre aydınlanma hem insanlığın ortak bir değeri olarak tarih içinde zorunlu bir gelişme göstermektedir hem de insanlığın bu ortak değerini herkesin savunması ve uygulanması gerekir. İnsanın başkalarının kılavuzluğu olmadan özgür düşünmesinin önündeki engeller hem giderek azalmakta hem de mevcut engellerin kaldırılması bir gereklilik olarak görülmektedir. İnsan özgürlüğünü benimseyen birinin bu tür bir aydınlanma anlayışına karşı çıkması neredeyse imkansızdır, çünkü bu şekilde bir aydınlanma ideali masum bir özgürlük savunusundan başka bir şey olarak görülmez. Bununla birlikte, insanın özgürlüğünü değil de toplumsal bütünlük ve düzenin öncelikli olduğunu düşünenler, tümüyle özgür düşünceye dayalı bir aydınlanma fikrine karşı çıkarlar. Mutlak özgürlüğün toplumsal hayatın ve bütünlüğün yıkımı anlamına geleceğini savunanlar kısmi özgürlük fikrini benimserler. Kısmi özgürlük düzenle uyum içinde bir özgürlük demektir. Düzeni sarsmayacak derecede özgür düşünceye izin verilmesi olarak bu tutum aydınlanmanın temel esprisine ters değildir. Bu bağlamda, özgürlük ve düzen hakkında uzun tarihi olan bir literatür ve hararetli tartışmalar bulunmasına karşın, demokrasi fikrinin bu iki ucun birbiriyle uyumunu düzenleyen bir temel çerçeve olduğunu görmekteyiz. Özgür düşünce olarak aydınlanmanın söz konusu iki biçimde yorumlanmasının soyut, evrensel ve Batılı düşünce geleneğinin parçası olduğunu söyleyebiliriz.

Batı dışı dünyada aydınlanma kendiliğinden ortaya çıkan bir gelişme değildir. Aydınlanma, Batının dünya üzerinde egemenlik kurma sürecinde Batı dışı toplumlara taşınan bir hareket ve değerdir. Bu çerçevede öncelikle pratikte aydınlanmanın evrenselliğiyle ilgili kaçınılmaz bir sorun ortaya çıkmaktadır. Batı dışı dünyada aydınlanma sorunu dışarıdan dayatılan bir değişme tasarımıyla birlikte yaşanmıştır. $\mathrm{Bu}$ değişim süreci en temelde modernleşme olarak ifade bulmuştur. Yani aydınlanma, modernleşme süreci içinde ortaya çıkması beklenen bir gelişme olarak düşünülebilir. Aydınlanma, modernleşmenin yaratıcısı değil sonucu olarak ortaya çıkmaktadır. Batıda aydınlanma oynadığı öncü rolüyle modernleşmenin kurucularından biri olarak rol oynadığı halde, en azından, modernliğin inşasında tekno-ekonomik süreçler kadar tayin edici tarihsel bir işlev gördügü halde, Batı dışı toplumlarda ise aydınlanma daha çok tekno-ekonomik değişimin bir sonucu, daha esnek bir ifadeyle bu sürecin bir parçası olarak görülmektedir. Burada kendini gösteren temel sorun öncelikle Kant'ın aydınlanma hakkındaki metinlerinde ifade bulmamıştır: Kant'ta aydınlanma birey için veya kolektif bir insan varlığı için başkalarının yönlendirmesi olmadan kendi aklını özgürce kullanmayı gerektirdiği halde Batı dışı bağlamlarda aydınlanma başkalarının yönlendirmesiyle ortaya çıkmaktadır. $\mathrm{Bu}$ anlamda bugüne kadar varlığını hissettiren ve bundan sonra da hissettirecek gibi görünen çelişki buradadır: yönlendirilmemek için yönlendirilmek. Kant'ın aydınlanma sorusunu ele aldığı metinde cevabını bulamadığımız soru bununla ilgilidir. Yönlendirilmemek için yönlendirilmek aydınlanma mıdır? Aklını başkalarının yönlendirmesinden kurtarmak için bir kimseyi, grubu veya ulusu en hafif tabirle yönlendirmek veya daha sert ifadeyle zorlamak bir aydınlanma biçimi midir? Soruyu bir aşama daha ileri götürürsek; bir kimsenin aklını başkalarının yönlendirmesi olmadan özgürce kullanmasını sağlamak için dışarıdan bir zorlama veya dayatma uygulamak aydınlanmanın gerçekleşmesine yardımcı olabilir mi? Kant'ın cevaplarını saf aklın ışı̆̆ı altında ele aldığımızda aydınlanmanın 
gerekliliklerine yönelik bir itiraz getirilmesi son derece güçtür. Ancak Batı sömürgeciliği ve hegemonyası gibi tarihsel süreçleri pratik aklın bir boyutu olarak ele aldı̆̆ımızda aydınlanma sürecinin kendiliğinden bir süreç olmadığını ya da tarihin kendiliğinden akışı diyebileceğimiz bir aydınlanma gerçekliği bulunmadığını görebiliriz. Aydınlanmanın tarihsel olarak yönlendirilmiş bir hareket olarak kendini göstermesi tam da aydınlanmanın tanımlayıcı özelliğinin hilafına bir işleyişin olması demektir. Çünkü Kant'ın ele aldığı biçimiyle aydınlanma, aklın özgürce kullanımını gerektirdiği kadar başkalarının yönlendirmesinden kurtulmayı da gerektirir. Oysaki Batı egemenliği altındaki toplumlarda tarihsel aydınlanma süreci, yönlendirmenin egemen olması anlamına gelmektedir.

Sonuç olarak, özgür düşünme günümüzde dünya genelinde düşüncenin temel gündemi olmay1 sürdürmektedir. Bununla birlikte, farklı toplumsal ve tarihsel bağlamlardaki bu gündemlerin her birinin Kant'ın metninde ilgi gösterdiğinden çok farklı boyutlarının olduğu görülmektedir. $\mathrm{Bu}$ çerçevede, evrensel bir ilke olarak özgür düşünmenin eleştirilerle karşılaştığını görmekteyiz. $\mathrm{Bu}$ eleştirilerden bazıları özgür düşünceyi savunduğu halde, özgür düşüncenin pratikte deneyimlenme biçimlerini dikkate almaktadır. Bu açıdan aydınlanma, spesifik düşünce biçimleri ve gelenekleriyle karşılaştığında ve ilişkilendirildiğinde önemli sorunlarla karşılaşmaktadır. Bunun nedeni, özgür düşünceye bağlamdan bağımsız evrensel bir değer yüklendiğinde kendisini bir dayatma olarak göstermesidir, evrensel bir değer yüklenmediğinde ise farklı geleneklerin özgür düşünceyi benimsemeleri doğrultusunda harekete geçirilmesinin önüne engellerin çıkmasıdır. Daha özel olarak, aydınlanmanın tarihsel kültürel olarak özel bir bağlamda, Batı tarihi içinde ortaya çıkmış olması, farklı uygarlıklarda gelişmesinde handikaplarla karşılaşmasına, Batı'nın dünyanın diğer toplumlarıyla egemenlik talepli ilişkisi dolayısıyla çoğu durumda bir dayatma olarak kavranmasına yol açmaktadır. $\mathrm{Bu}$ şekilde ortaya çıkan temel bir deneyim, tüm çelişkileriyle birlikte söylersek, özgür düşünmenin yönlendirmeyle ve dayatmayla birlikte gelişmesidir. Yani, aydınlanma, Batı dışı bağlamlarda yönlendirilmemek için yönlendirilmek olarak kendini göstermektedir. Bu şekildeki bir süreç en azında iki yüzyıldan daha uzun zaman boyunca aydınlanmanın kendisini gösterme biçimidir.

Kant'ın Aufklärung sorusuyla temelinde günümüz koşullarında daha geçerli bir eleştiri, kendilikle, kendiliğin oluşturulma biçimleriyle ilişkilidir. Frankfurt Okulu'nun kültür endüstrisi veya Foucault'nun iktidar ve disiplin kavramları çerçevesinde sorguladığı gibi veya başka biçimlerde kendilik pratikleri kendiliğin özgürce düşünülmesine ne kadar imkân vermektedir? Günümüzde kendiliğin tekno-kültürel paketler ve otomasyon biçimleri vasıtasıyla oluşturulması aydınlanma sorusunu değerlendirmenin en hayati boyutunu oluşturmaktadır. Dolayısıyla dünya çapında tek bir uygarlığın egemen olduğu, Doğu ve Batı kavramlarının geçerliliklerini kaybettikleri, küreselliğin gündelik yaşamın akışını belirlediği günümüzde aydınlanmayla ilgili kritik soru şudur: Kendiliğin tekno-kültürel paketlerden ve yönlendirmelerden kurtularak özgürce düşünmeyle ergen olmayıştan çıkışı ne derece mümkündür?

\section{KAYNAKÇA}

Abbinnett, Ross. "Politics and Enlightenment: Kant and Derrida on Cosmopolitan Responsibility." Citizenship Studies 2 (1998): 197-222.

Adorno, Thodor W. ve Horkheimer, Max. Aydınlanmanın Diyalektiği. Çev. Elif Öztarhan Karadoğan. İstanbul: Kabalcı Yayınları, 2010.

Akça, Gürsoy ve Hülür, Himmet. "Osmanl1-Türk Düşüncesindeki Doğu-Bati İmgelerini Küreselleşme Tartışmaları Bağlamında Yeniden Düşünmek." Selçuk Üniversitesi Türkiyat Araştırmaları Enstitüsü Türkiyat Araştırmaları Dergisi 16 (2004): 259-282.

Aquilina, Aaron. "Reprogramming Destiny: Kant's 'What is Enlightenment?" Evolution, and Posthumanism. A Journal of Literary Studies and Linguistics VI (2016): 130-148.

Baghai, Farshid. "The Disciplinary Conception of Enlightenment in Kant's Critical Philosophy." Critical Horizons 21 (2020): 130-152.

Benson, Bruce E. (1985). "Escaping the Blackmail of the Enlightenment: Kant, Foucault, and Gadamer on The Meaning of Maturity." Common Ground Journal 12 (1985): 77-88. 
Breackman, Antoon. "The Moral Inevitability of Enlightenment and the Precariousness of the Moment: Reading Kant's What is Enlightenment." The Review of Metaphysics 62 (2008): 285350 .

Cascardi, Anthony J. "Aesthetic Liberalism: Kant and the Ethics of Modernity." Revue Internationale de Philosophie 45 (1991): 10-23.

Chatterjee, Partha. Our Modernity. Rotterdam and Dakar: SEPHIS and CODESRIA, 1997.

Cronin, Ciaran. Kant's Politics of Enlightenment. Journal of History of Philosophy 41 (2003): 51-80.

De Kadt, Raphael. "Modernity and the Future of Democracy." Theoria: A Journal of Social and Political Theory 74 (1989): 45-58.

Deligiorgi, Katerina. Kant and the Culture of Enligtenment. Albany: State University of New York Press, 2005.

Dmitreva, Nina A. "Back to Kant, or Forward to Enlightenment: The Particularities and Issues of Russian Neo-Kantianism.” Russian Studies in Philosophy 54 (2016): 378-394.

Dostal, Robert. "Gadamer, Kant, and the Enlightenment." Research in Phenomonology 46 (2016): 337-348.

Fehér, Ferenc. "Practical Reason in the Revolution: Kant's Dialogue with the French Revolution." Social Research 56 (1989): 169-181.

Flesichacker, Sam. “Kant's Enlightenment.” International Journal of Philosophy, 2 (2015): 177-196.

Foucault, Michel. Hapishanenin Doğuşu. Çev. Mehmet Ali Kılıçbay. Ankara: İmge Kitabevi Yayınlar1, 2001.

Foucault, Michel. Özne ve İktidar. Çev. Işı Ergüden ve Osman Akınhay. İstanbul: Ayrıntı Yayınları, 2000.

Gilligan, Carol. Kadının Farklı Sesi: Psikolojik Kuram ve Kadının Gelişimi. Çev. Duygu Dinçer, Fulden Arısan, Merve Elma. İstanbul: Pinhan Yayınları, 2017.

Habermas, Jürgen. "Taking Aim at the Heart of the Present." Foucault: A Critical Reader. D. Couzens Hoy. Oxford: Basil Blackwell, 1986. 103-108.

Habermas, Jürgen. "Modernity: An Unfinished Project". Habermas and the Unfinished Project of Modernity. Maruzio Passerin d'Entrèves and Seyla Benhabib. Cambridge: The MIT Press, 1997. 38-58.

Kant, Immanuel. Practical Philosophy. Tr. and ed. by Mary J. Gregor. Cambridge: Cambridge University Press, 1996.

Kant, Immanuel. The Conflict of the Faculties. Tr. and int. by M. J. Gregor. New York: Abaris Books, Inc, 1979.

Linker, Damon. "From Kant to Schelling: Counter-Enlightenment in the Name of Reason." The Review of Metaphysics 54 (2000): 337-377.

Mack, Michael. "Freud's Other Enlightenment: Turning the Tables on Kant." New German Critique, 85 (2002): 3-31.

Mensch, Jennifer. "Seeds of Divinity: From Metaphysics to Enlightenment in Ficino and Kant." Intellectual History Review, 29 (2019): 183-198.

Piche, Claude. "Kantian Enlightenment as a Critique of Culture." International Journal of Philosophy 2 (2015): 197-216.

Raffnsøe, Severre., Thaning, Morten S., Gudmand-Høyer, Marius. "Philosophical Practice as Selfmodification: An Essay on Michel Foucault's Critical Engagement with Philosophy." Foucault Studies 25 (2018): 8-54. 
Richter, Gerhard. Afterness: Figures of Following in Modern Thought and Aesthetics. New York: Columbia University Press, 2011.

Rumore, Paola. "Kant's Understanding of the Enlightenment with Reference to his Refutation of Materialism." Con-Textos Kantianos. International Journal of Philosophy 1 (2014): 81-97.

Ürek, Ogün. "Kant'ta Aydınlanmanın Olanağı Olarak İnsana Saygı." U. Ü. Fen-Edebiyat Fakültesi Sosyal Bilimler Dergisi 2 (2001): 17-24.

Westphal, Kenneth R. "Enlightenment, Reason and Universalism: Kant's Critical Insights." Stud East Eur Thought, 68 (2016): 127-148.

Wilson, Holly L. "Kant's Experiential Enlightenment and Court Philosophy in the 18th Century." History of Philosophy Quarterly 18 (2001): 179-205.

Zhang, Wei. What is Enlightenment: Can China Answer Kant's Question? Albany: State University of New York Press, 2010. 